\title{
WILD SPECIES OF Helianthus L. - SOURCES OF RESISTANCE TO THE PARASITE Orobanche cumana Wallr.
}

\author{
Christov, M. ${ }^{*}$, Batchvarova, R., Hristova-Cherbadzhi, M.
}

Dobroudja Agricultural Institute - General Toshevo 9520, Bulgaria

Received: July 15, 2009 Accepted: November 10, 2009

\begin{abstract}
SUMMARY
Accessions from different Helianthus species, cultivated sunflower forms and interspecific hybrid forms and lines were included in this investigation. It was established that broomrape resistance was transferred from 11 perennial Helianthus species to interspecific hybrids developed on the basis of new sunflower lines. Some of the new lines possessed other desirable agronomical characters, which could be successfully transferred to new sunflower hybrid cultivars. Differences were observed in the origin of broomrapes found in different locations of northern Bulgaria. Diverse origin of some of the obtained sunflower forms was confirmed using the RAPD analysis.
\end{abstract}

\section{Key words: Helianthus, interspecific hybrids, resistance, Orobanche cumana Wallr., RAPD analysis, random decamer primers}

\section{INTRODUCTION}

Broomrape of sunflowers (Orobanche cumana Wallr.) is an annual, highly specialized parasite. It attaches to its host and grows together with it. Its stem is single, unbranched and reaches a height of $80 \mathrm{~cm}$. Flowers are pollinated usually by insects, but seeds can be formed after self pollination too. It is distinguished for a high productive coefficient. It has been noted that broomrape seeds develop faster when close to sunflower roots.

The parasite Orobanche cumana Wallr. present in Bulgaria attacks sunflowers and several wild plants such as Artemisia maritima L. and Cihoria intibus L (Petrov, 1962).

The first report for the broomrape presence was published by A. Oldanov in 1886. In the 1890s it spread over an enormous area on the territory of Russia. Large yield reductions became regular occurrence in recent years (Kukin, 1982).

* Corresponding author: Phone: +35958603125; Fax: +35957314448;

e-mail: michailhristov@yahoo.com 
This parasite causes formidable yield damages around the world each year, but especially in the countries in southeastern Europe, Middle East and the Mediterranean region (Cubero, 1986; Melero-Vera et al., 1989 and etc.). An intensive attack by the parasite delays stops the growth of sunflower plants. Seed yield is decreased and in most cases absent altogether. Bachvarova (2004) pointed out that broomrape attack reduced plant height by $6.4 \%$, head diameter by $27.8 \%$, while yield was decreased seven times.

There are six or, according to other authors, seven broomrape races: A, B, C, D, $\mathrm{E}, \mathrm{F}$ and $\mathrm{H}$. This showed that the parasite possessed a high level of variability. As a result of the genetic variability and population ecology of broomrape, the host resistance was often overcome by new physiological races (Bachvarova, 1978a,b; Shindrova, 1994 and etc.). Studies of Shindrova (2006) showed that there were three broomrape races in Bulgaria - D, E and F. Race E was widely distributed in all sunflower-growing regions. Race $\mathrm{F}$ was new for the country.

The permanent problem with broomrape spread asked for permanent research work in the filed, searching for new sunflower materials resistant to the new races. Different ways for controlling parasite attacks were tested (different methods of soil cultivation, herbicides use, biological agents, etc.), which gave no viable practical results.

Till now the broomrape problem was mainly solved by genetic means, by finding new resistance sources and developing new sunflower material resistant to the new parasite races.

In our investigations we used different, known or supposed sources of resistance to the parasite. The permanent task in developing of new sunflower forms and lines was collecting, study and use of initial material, which possessed genes for control of different races. We have collected numerous native populations, cultivars and other cultivated forms from Russia, Ukraine, Romania, Spain, Israel, Turkey and Bulgaria, mutant forms originating from different cultivars and lines, wild Helianthus species, and sunflower forms obtained by mass hybridization and combined use of experimental mutagenesis and mass selection. Many of our own experiments (Christov, 1990; Christov, 1996; Christov et al., 1996 and etc.) indicated that full resistance to broomrape existed in perennial Helianthus species.

Many of Helianthus species, annual and perennial, showed broomrape resistance when tested by inoculation methods under field and laboratory conditions . There was a lack of resistance in $\mathrm{F}_{1}\left(\mathrm{BC}_{1}\right)$ hybrids for some of there accessions, obtained from the crosses with susceptible cultivated forms. This showed that not a single accession, from one and the same species, could ensure lasting resistance, especially to the most virulent parasite races.

Resistance which was noted in $\mathrm{F}_{1}\left(\mathrm{BC}_{1}\right)$ hybrids, obtained from interspecific crossing, originated from perennial and some annual species. That is why our interest was directed to perennial sunflowers, despite difficulties associated with their use.

The aim of this study was to present the obtained results and discuss opportunities for developing new forms and lines resistant to broomrape drawing origin 
from interspecific hybrids obtained by crossing cultivated sunflower and wild Helianthus species.

\section{MATERIAL AND METHODS}

This investigation included 17 accessions from 13 perennial and three annual Helianthus species; 4 cultivated sunflower lines 1607, 2607, 6076, HA 89, the cultivar Peredovik, susceptible to broomrape and interspecific hybrid forms and lines, obtained from 11 perennial species - Helianthus ciliaris, $H$. decapetalus, $H$. divaricatus, $H$. eggertii, $H$. hirsutus, $H$. maximiliani, $H$. nuttallii ssp. rydbergi, $H$. pumilus, $H$. rigidus, $H$. smithii, $H$. tuberosus, which carried the resistance. To select desired Helianthus accessions, we used information from previous investigations (Christov, 1990; Christov, 1996). In some studies three additional mutant forms were used - № 6116B, MX199/2, MX655/1 and the cultivar Vega. Broomrape seeds used for evaluation of the sunflower material were collected from four different location in northern Bulgaria.

Broomrape resistance evaluation was done according to Panchenko (1975), Christov (1990), Christov et al. (19920 and Christov (1996), in nurseries and in field conditions, and for some diseases according to Christov (1990), Christov et al. (1992) and Christov (1996).

Table 1: Evaluation of Helianthus species for resistance to broomrape, Sclerotinia and downy mildew

\begin{tabular}{llccc}
\hline \multirow{2}{*}{ № } & \multirow{2}{*}{ Species and accession number } & \multicolumn{3}{c}{ Resistance to inoculation, \% } \\
\cline { 3 - 5 } & & Broomrape & Sclerotinia & Downy \\
\hline 1 & H. ciliaris M 092 & 100 & 100 & 95 \\
2 & H. decapetalus M 043 & 100 & 90 & 100 \\
3 & H. divaricatus M 044 & 100 & 67 & 100 \\
4 & H. eggertii & 100 & 85 & 90 \\
5 & H. hirsutus M 029 & 95 & 95 & 100 \\
6 & H. maximiliani M 017 & 100 & 66 & 100 \\
7 & H. nuttallii ssp. rydbergi M 173 & 100 & 75 & 100 \\
8 & H. pumilus M 172 & 100 & 50 & 100 \\
9 & H. pauciflorus M 002 & 100 & 25 & 100 \\
10 & H. pauciflorus ssp. rigidus M 028 & 100 & 87 & 100 \\
11 & H. smithii M 008 & 100 & 75 & 100 \\
12 & H. tuberosus M 037 & 100 & 33 & 100 \\
13 & H. mollis M 034 & 97 & 56 & 100 \\
14 & H. resinosus M 046 & 63.2 & 85 & 100 \\
15 & H. debilis E 011 & 90 & 60 & 90 \\
16 & H. agrophyllus E 131 & 75 & 50 & 86 \\
17 & H. annuus (lenticularis) E 003 & 60 & 33 & 60 \\
18 & H. annuus-L 1607 & 0 & 0 & 0 \\
19 & H. annuus-L 2607 & 0 & 0 & 100 \\
20 & H. annuus-L 6075 & 0 & 0 & 0 \\
21 & H. annuus-L HA 89 & 0 & 0 & 0 \\
22 & H. annuus-Peredovik-St & 0 & 0 & 0 \\
\hline
\end{tabular}




\section{RESULTS AND DISCUSSION}

Orobanche cumana Wallr. resistance was tested in 17 accessions from 16 wild Helianthus species, four lines and one cultivar. The results presented in Table 1 show that presence of resistance genes was established or confirmed in all 17 Helianthus accessions. The results also confirmed that the evaluated accessions were donors of genes for resistance/tolerance to some diseases of economic importance. Most of the accessions had the resistance to broomrape and downy mildew of $100 \%$ or lower. Each of the two resistance sources was controlled by one dominant gene. The lower percentage of resistance was defined by the population character of the studied accessions.

Interesting results were obtained in the study of hybrid forms $F_{1}$ and $B_{1}$. Some of these are presented in Table 2 . The resistance to broomrape established in 11 of the studied perennial Helianthus species was successfully transferred to interspecific hybrids.

The number of resistant crosses was larger in $\mathrm{BC}_{1}$. Table 2 shows only the $\mathrm{BC}_{1}$ forms with a certain level of resistance. Some $\mathrm{BC}_{1}$ forms lost their resistance, especially backcrosses with cultivated lines.

Table 2: Evaluation for resistance to broomrape of some $\mathrm{F}_{1}$ and $\mathrm{BC}_{1}$ interspecific hybrids

\begin{tabular}{|c|c|c|}
\hline № & $\mathrm{F}_{1}\left(\mathrm{BC}_{1}\right)$ from the cross & Resistance to inoculation, \% \\
\hline 1 & $\mathrm{~F}_{1} \mathrm{H}$. annuus-HA $89 \mathrm{~A} \times \mathrm{H}$. maximiliani $\mathrm{M} 017$ & 100 \\
\hline 2 & $\mathrm{~F}_{1} \mathrm{H}$. annuus-HA $89 \mathrm{~A} \times \mathrm{H}$. divaricatus M 044 & 100 \\
\hline 3 & $\mathrm{~F}_{1}$ H. annuus-HA $89 \mathrm{~A} \times$ H. n. rydbergii M 173 & 90 \\
\hline 4 & $\mathrm{~F}_{1} \mathrm{H}$. annuus-6075A $\times$ H. pumilus $\mathrm{M} 172$ & 100 \\
\hline 5 & $\mathrm{~F}_{1} \mathrm{H}$. annuus-2607A $\times$ H. smithii M 008 & 95 \\
\hline 6 & $\mathrm{~F}_{1} \mathrm{H}$. annuus-HA $89 \mathrm{~A} \times \mathrm{H}$. eggertii M 001 & 94.7 \\
\hline 7 & $\mathrm{~F}_{1}$ H. annuus-HA $89 \mathrm{~A} \times$ H. hirsutus M 029 & 80 \\
\hline 8 & $\mathrm{BC}_{1} 2607 \mathrm{~A} \times(H$. annuus $-2607 \mathrm{~A} \times$ H.ciliaris $\mathrm{M}$ 092 $)$ & 36.8 \\
\hline 9 & $\mathrm{BC}_{1}$ HA 89A $(H$. annuus-1607A $\times$ H. decapetalus-M 043) & 70 \\
\hline 10 & $\mathrm{BC}_{1}$ HA 89A $(H$. annuus-1607A $\times$ H. hirsutus M 029) & 21.1 \\
\hline 11 & $\mathrm{BC}_{1} 2607 \mathrm{~A} \times(H$. annuus-1607A $\times H$. eggertii-M 001) & 30 \\
\hline 12 & $\mathrm{BC}_{1} 1607 \mathrm{~A} \times(\mathrm{H}$. annuus-1607A $\times H$. tuberosus-M 037) & 65 \\
\hline 13 & $\mathrm{BC}_{1} 2607 \mathrm{~A} \times(H$. annuus-2607A $\times$ H. pauciflorus $-\mathrm{M}$ 002 $)$ & 45 \\
\hline 14 & $\mathrm{BC}_{1} 1607 \mathrm{~A} \times(\mathrm{H}$. annuus-1607A $\times$ H. pauciflorus-M 028) & 68.4 \\
\hline 15 & $\mathrm{BC}_{1} \mathrm{HA} 89 \mathrm{~A} \times(H$. eggertii-M $001 \times H$. annuus-HA 89B $)$ & 40 \\
\hline 16 & $\mathrm{BC}_{1}$ 2607A $\times($ H. tuberosus-M $037 \times$ H. annuus-2607B $)$ & 42.1 \\
\hline 17 & $\mathrm{BC}_{1}$ HA $89 \mathrm{~A} \times(H$. pauciflorus-M $028 \times H$. annuus-1607B $)$ & 52.6 \\
\hline 18 & $\mathrm{BC}_{1}$ (H. decapetalus-M $043 \times$ Peredovik $) \times 1607 \mathrm{~B}$ & 68.4 \\
\hline 19 & $\mathrm{BC}_{1}(\mathrm{H}$. hirsutus M $029 \times 1607 \mathrm{~B}) \times$ Peredovik & 45 \\
\hline 20 & $\mathrm{BC}_{1}(\mathrm{H}$. eggertii-M $001 \times$ H. annuus-HA 89B $) \times$ Peredovik & 57.9 \\
\hline 21 & $\mathrm{BC}_{1}$ (H. tuberosus-M $037 \times$ H. annuus-2607B) $\times$ HA 89B & 15 \\
\hline
\end{tabular}

To obtain subsequent generations, only viable and resistant plants were selected and self-pollinated in isolation. 
Table 3 shows some data for the newly developed sunflower materials. They had a high level of resistance - $100 \%$. This was obviously due to the fact that all the wild species included in the investigation were resistant to the studied complex of races present in Bulgaria.

Table 3: Evaluation of sunflower forms and lines for resistance to broomrape and downy mildew

\begin{tabular}{llcc}
\hline \multirow{2}{*}{ № } & Pedigree & \multicolumn{2}{c}{ Resistance to inoculation, \% } \\
\cline { 3 - 4 } & & Broomrape & Downy mildew \\
\hline 7009R & 1607A $\times($ H. annuus-1607A $\times$ H. tuberosus-M 037) & 100 & 100 \\
7043/2R & 1607A $\times($ H. annuus-1607A $\times$ H. pauciflorus-M 028) & 100 & 100 \\
7122R & 6075A $\times($ H. annuus-1607A $\times$ H. pauciflorus-M 028) & 100 & 100 \\
7203R & HA 89A $\times($ H. annuus-1607A $\times$ H. decapetalus-M 043) & 100 & 100 \\
7026R & H. annuus-2607A $\times$ H. smithii M 008 & 100 & 100 \\
7091R & 2607A $\times($ H. annuus-2607A $\times$ H.ciliaris M 092) & 100 & 100 \\
7079R & H. annuus-HA 89A $\times$ H. maximiliani M 017 & 100 & 100 \\
7047R & HA 89A $\times($ H. eggertii-M 001 $\times$ H. annuus-HA 89B $)$ & 100 & 100 \\
& H. annuus-HA 89A $\times$ H. n. rydbergii M 173 & 100 & 100 \\
& H. annuus-HA 89A $\times$ H. divaricatus M 044 & 100 & 100 \\
& H. annuus-HA 89A $\times$ H. maximiliani M 017 & 100 & 100 \\
6156B & H. annuus-6075A $\times$ H. pumilus M 172 & 100 & 100 \\
6748B & (H. eggertii-M 001 $\times$ H. annuus-HA 89B $) \times$ Peredovik & 100 & 100 \\
\hline
\end{tabular}

The objective of developing these materials was to obtain various positive characters such as resistance to some economically important diseases, high combining ability in lines and high productive potential, high seed oil content, etc. in hybrids.

Table 4 presents some of the newest $\mathrm{R}$ forms, distinguished for their full resistance to broomrape and downy mildew and comparatively good seed oil content.

Table 4: Characterization of R sunflower forms with good combining ability and comparatively good productivity coefficient, harvest 2007

\begin{tabular}{llcccc}
\hline No Pedigree & $\begin{array}{c}\text { Resistance to } \\
\text { downy mildew, \% }\end{array}$ & $\begin{array}{c}\text { Resistance to } \\
\text { broomrape, } \%\end{array}$ & $\begin{array}{c}\text { Head } \\
\text { diameter, cm }\end{array}$ & $\begin{array}{c}\text { Oil content, } \\
\%\end{array}$ \\
\hline 1 & PR 1/7 (ot k.c. $\times$ H. pauciflorus) & 100 & 100 & 15 & 48.48 \\
2 & PR 5/7 (ot k.c. $\times$ H. tuberosus) & 100 & 100 & 15 & 55.04 \\
3 & PR 6/7 (ot k.c. $\times$ H. pauciflorus) & 100 & 100 & 16 & 54.27 \\
4 & PR 11/7 (ot k.c. $\times$ H. petiolaris) & 100 & 100 & 15 & 48.32 \\
5 & PR 31/7 (ot k.c. $\times$ H. pauciflorus) & 100 & 100 & 16 & 49.75 \\
6 & PR 41/7 (ot k.c. $\times$ H. divaricatus) & 100 & 100 & 18 & 47.41 \\
7 & PR 44/7 (ot k.c. $\times$ H. debilis) & 100 & 100 & 14 & 49.89 \\
8 & PR 54/7 (ot k.c. $\times$ H. hirsutus) & 100 & 100 & 16 & 47.36 \\
\hline
\end{tabular}

A vast spread of broomrape in Bulgaria was registered in the northern and sough-eastern parts of the country, where intensive attacks were registered in some regions. 
The study of reaction of sunflower lines and cultivars to the broomrapes collected in four regions of northern Bulgaria was carried out in nursery conditions. Table 5 shows that some differences occurred among the broomrapes from different regions and the most virulent was that from Svishtov region.

Line 7203R, originating from $H$. decapetalus-M 043, line 5M 044, originating from $H$. divaricatus M 044, line 7043/2R, originating from $H$. pauciflorus-M 028 and line 7047R, originating from $H$. eggertii-M 001, were distinguished with full resistance. Line 7009R, originating from $H$. tuberosus-M 037, was distinguished with high resistance.

Table 5: Attack intensity on sunflower lines and cultivars by broomrapes collected in different regions of northern Bulgaria

\begin{tabular}{lcccc}
\hline No & General Toshevo & Shabla-Krapetz & Lom & Svishtov \\
\hline $7009 \mathrm{R}$ & 0 & 10 & 0 & 10 \\
$7015 \mathrm{R}$ & 75 & 90 & - & 100 \\
$7041 \mathrm{R}$ & 40 & 100 & - & 100 \\
$7043 / 1 \mathrm{R}$ & 35 & 90 & - & 95 \\
$7043 / 2 \mathrm{R}$ & 0 & 0 & - & 0 \\
$7047 \mathrm{R}$ & 0 & 0 & - & 0 \\
$7203 \mathrm{R}$ & 0 & 0 & - & 0 \\
5 M 044 & 0 & 0 & - & 0 \\
MX199/2 & 0 & 0 & - & 0 \\
MX655/1 & 0 & 0 & 0 & 0 \\
$6116 \mathrm{~B}$ & 0 & 0 & 0 & 0 \\
$2607 \mathrm{~B}$ & 100 & 100 & 100 & 100 \\
Vega & 0 & 10 & 0 & 45 \\
Peredovik & 86 & 0 & - & 100 \\
\hline
\end{tabular}

The line 7009R was a parental component of the hybrids Maritza and Magura, the line 7043/1R of the hybrid Musala, and the line 7015R of the hybrids Mura and Mesta.

The female line of the hybrids Albena, Musala, Magura, Mura, etc., 2607B, showed complete susceptibility to the broomrape collected near the village of Krapetz. The average number of broomrapes was 6.1 (Table 6). In the R lines obtained from mass hybridization, the range of broomrape attack varied from 10 to $90 \%$. The highest resistance was established for the line $7009 \mathrm{R}$.

Table 6: Broomrape O. cumana Wallr. attacks on sunflower lines and cultivars under nursery conditions (3-year average)

\begin{tabular}{lcc}
\hline Line/cultivar & Average number of broomrapes per plant & Resistance, \% \\
\hline $7009 \mathrm{R}$ & 0.1 & 90 \\
$7015 \mathrm{R}$ & 6.2 & 10 \\
$7043 / 1 \mathrm{R}$ & 6.0 & 10 \\
$2607 \mathrm{~B}$ & 6.1 & 0 \\
$6116 \mathrm{~B}$ & 0 & 100 \\
Vega & 0.5 & 90 \\
Peredovik & 23.3 & 0 \\
\hline
\end{tabular}


Molecular analysis was carried with aim to determine markers associated with sunflower resistance to broomrape. The tested mutant lines MX655/1 and 6116B showed full resistance to all broomrape races present in Bulgaria.

RAPD analyses of cultivars and lines were carried out using 70 random decamer primers. Seven of the total of 70 primers used (OPA-02, OPA-11, OPB-01, OPB-10, OPB-13, OPB-18 and OPK-17 (OperonTechnologies Inc., USA) gave polymorphic products for the resistant forms, which were missing in the susceptible ones. Four of these primers (OPA-11, OPB-01, OPB-18 and OPK-17) amplified polymorphic fragments for all of the studied resistant forms (MX655/1, 6116B, Vega and 7009R). The remaining three primers (OPA-02, OPB-10 and OPB-13) gave polymorphic products only for three of the studied resistant lines. The results obtained with primers OPA-02, OPB-10 and OPB-13 seem to indicate that this was due to differences in the resistance to race $\mathrm{E}$ of $O$. Cumana.

Primers OPA-02 and OPB-13 amplified polymorphic products with the size of about $590 \mathrm{kD}$ and $850 \mathrm{kD}$, respectively, for the mutant lines MX655/1, 6116B and the cultivar Vega, but they were missing in the line $7009 \mathrm{R}$. The primer OPB-10 produced polymorphic fragments with the size $520 \mathrm{kD}$ for the mutant lines MX655/1, $6116 \mathrm{~B}$ and line 7009R, but not for the cultivar Vega.

\section{CONCLUSION}

The obtained results showed and confirmed the findings of other authors that wild Helianthus species are potential sources of resistance to the parasite Orobanche cumana Wallr. It was established that resistance to broomrape was transferred to new sunflower forms, lines and interspecific hybrids. The evaluation of reaction of several new sunflower lines to broomrape samples collected from different locations in northern Bulgaria showed that differences existed among the broomrape of different origin. RAPD analyses confirmed the different origins of the line $7009 \mathrm{R}$, the other two mutant forms and the cultivar Vega.

\section{REFERENCES}

Bachvarova, R., 1978a. Proucvane virulentnostta i specializacijata na sinja kitka Orobanche sp. varhu slanchogleda. Disertacija PhD, SA, Sofia.

Bachvarova, R., 1978b. Izsledvanija varhu raznoobrazieto i patogeniteta na pet proizhoda sinja kitka pri slanchogled. Rastenievadni nauki № 3 .

Bachvarova, R., 2004. Proucvane varhu sinjata kitka (Orobanche spp.) pri slanchogled i tyutyun. Disertacija „Doctor of scientist”, Sofia.

Christov, M. 1990. Prouchvane na divi vidove ot rod Helianthus s ogled izpolzvaneto im v selekciata na slanchogleda. Disertacija PhD, SA, Sofia.

Christov, M., 1996. Hybridization of cultivated sunflower and wild Helianthus species. In: Caligari, P.D.S. and Hind, D.J.N. [Eds.], Compositae: Biology and Utilization. Proceedings of the International Compositae Conference, Kew, 1994. Royal Botanic Gardens, Kew 2: 603-615. 
Christov, M., Shindrova, P., Encheva, V., 1992. Phytopathological characterization of wild species in the genus Helianthus in view of their use in breeding for resistance. Genetics and Breeding 25(1): 45-51.

Christov M., Shindrova, P., Entcheva, V., 1996. Transfer of new characters from wild Helianthus species to cultivated sunflower. Genet. y Slecht., 32, (4): 275- 286.

Christov M., Shindrova, P., Entcheva, V., Bachvarova, R., Christova, M., 1998. New sunflower forms resistant to broomrape. In: Wegmann, K., Musselman, L.J. and Joel, D.M. [Eds.], Current Problems of Orobanche Research. Proceedings of the $4^{\text {th }}$ International Workshop on Orobanche Research, Albena, Bulgaria: Institute for Wheat and Sunflower Dobroudja, September 23-26, Albena, Bulgaria pp. 317-319.

Cubero, J.I. 1986. Breeding for resistance to Orobanche and Striga: a review. In ter Borg, S.J., [ed.] Proc. Workshop on Biology and Control of Orobanche. Wageningen, The Netherlands: LH/VPO, pp. 127-139.

Kukin, V.F., 1982. Bolezni podsolnecnika i meri borbi s nimi. „Colos”, Moskva.

Melero-Vera J.M., Dominguez, J. and Fernandez-Martinez, J.M., 1989. Evaluation of differential lines and collection of sunflower parental lines for resistance to broomrape (Orobanche cernua) in Spain. Plant Breeding 102: 322-326.

Panchenko A., 1975. Rannaya diagnostika zarazihoustoicivosti pri selekcii i ulucshayushtem semenovodstve podsolnecnika. Vestnik selskohozyaistvennoi nauki 2: 107-115.

Petrov D., 1962. Slanchogledat v Balgaria. DI, Varna.

Shindrova P., 1994. Distribution and race complex of Broomrape (Orobanche cumana Wallr.) in Bulgaria. In: Pieterse, A.H., Verkleij, J.A.C. and ter Borg, S.J. [Eds.] Biology and Management of Orobanche, Proc. $3^{\text {rd }}$ Int. Workshop on Orobanche and Related Striga Research. Amsterdam: The Netherlands, Royal Tropical Institute pp. 142-145.

Shindrova P., 2006. Broomrape (Orobanche cumana Wallr.) in Bulgaria - distribution and race composition. Helia 29(44): 111-120.

\title{
LAS ESPECIES SILVESTRES DE Helianthus L. -FUENTES DE RESISTENCIA AL PARÁSITO Orobanche cumana Wallr.
}

En esta investigación se incluyeron introducciones de diferentes especies de Helianthus, así como girasol cultivado, híbridos interespecíficos y líneas. La resistencia al jopo se transfirió desde 11 especies perennes de Helianthus perennes hacia híbridos interespecíficos y, sobre esa base, se desarrollaron nuevas formas de girasol y líneas. Algunas de las nuevas líneas poseían otros caracteres agronómicos adicionales, los que pudieron ser transferidos con éxito a nuevos híbridos de girasol. Se observaron diferencias en el origen del jopo encontrado en distintas localidades del norte de Bulgaria. El origen diverso de algunas de las formas obtenidas de girasol fue confirmado mediante RAPD.

\section{ESPÈCES SAUVAGES DE TOURNESOL Helianthus L. - SOURCES DE RÉSISTANCE AU PARASITE Orobanche cumana Wallr.}

\author{
RÉSUMÉ
}

Des échantillons de différentes espèces d'Helianthus, formes cultivées de tournesol, hybrides interspécifiques et lignées ont été utilisés dans cette expérience.

Il est rapporté que la résistance au parasite Orobanche a été transférée à partir de 11 espèces pérennes d'Helianthus par croisements interspécifiques, à partir de cette base de nouveaux germplasm et lignées ont été développés. 
Certaines de ces nouvelles lignées possèdent d'autres caractères agronomiques uniques qui pourraient être transférés avec succès à de nouveaux cultivars hybrides de tournesol.

Des différences ont été observées dans les origines d'Orobanche trouvées dans différents endroits au nord de la Bulgarie. L'origine diverse de certaines des formes de tournesol obtenues a été confirmée par des analyses RAPD. 
Paper presented at the International Symposium on broomrape (Orobanche spp. ) in sunflower, organized by the Trakya Agricultural Research Institute, held in Antalya, Turkey, from November 30 to December 3,2008. 